\title{
The anesthetic effect of propofol or etomidate in geriatric dogs premedicated with butorphanol and diazepam
}

\author{
Shahid Hussain Dar ${ }^{1 *}$, Ramamurthy Jayaprakash², Ravi Sundar George², \\ Shazia Nissar ${ }^{1}$, Mohammad Shafiuzamma ${ }^{2}$, and Thadavan Arthanari Kannan ${ }^{3}$ \\ ${ }^{I}$ Veterinary Clinical Complex, Faculty of Veterinary Sciences and Animal Husbandry, SKUAST-Kashmir, Jammu \\ and Kashmir, India
}

${ }^{2}$ Division of Veterinary Surgery and Radiology, Madras Veterinary College, TANUVAS, Chennai, India

${ }^{3}$ Division of Veterinary Anatomy, Madras Veterinary College, TANUVAS, Chennai, India

HUSSAIN DAR, S., R. JAYAPRAKASH, R. SUNDAR GEORGE, S. NISSAR, M. SHAFIUZAMMA, T. ARTHANARI KANNAN: The anesthetic effect of propofol or etomidate in geriatric dogs premedicated with butorphanol and diazepam. Vet. arhiv 89, 831-838, 2019.

\section{ABSTRACT}

The study was conducted in geriatric dogs to evaluate the anesthetic effect of propofol and etomidate in dogs premedicated with butorphanol and diazepam. Twelve adult dogs (males and females) were used in the study and were randomly divided into two groups viz. group P (propofol) and group E (etomidate) six animals each. The dogs were premedicated with diazepam $0.25 \mathrm{mg} / \mathrm{kg}$ and butorphanol $0.2 \mathrm{mg} / \mathrm{kg}$ fifteen minutes before induction intravenously and separately. General anesthesia was induced with propofol $2 \mathrm{mg} / \mathrm{kg}$ in group P or etomidate $1 \mathrm{mg} / \mathrm{kg}$ in group E to effect and drugs were administered rapidly over a period of 45 seconds up to effect. Induction quality, recovery quality, and ataxia scores were recorded for each dog. Cardiopulmonary parameters (respiratory, pulse rates, pulse oximeter, and ECG recordings) were recorded before induction and immediately after intubation and before connection to the inhalant gas machine, using a multi-parameter monitor. The mean $\pm \mathrm{SE}$ induction doses for the propofol and etomidate groups were $2.2 \pm 0.16$ and $0.97 \pm$ $0.15 \mathrm{mg} / \mathrm{kg}$ respectively. Smooth intubation was observed in the propofol group as compared to the etomidate group, as laryngeal reflex was intact in this group. Physiological parameters (pulse rate, respiratory rate, pulse oximeter, capillary refill time, mucous membrane color, ECG recordings and blood pressure) did not vary significantly between the two groups during the anesthesia. There were more adverse reactions in the etomidate group as compared to the propofol group, but the differences were not significant. Neither of the anesthetics, etomidate and propofol, in dogs premedicated with butorphanol and diazepam, had any major adverse effect on the cardiopulmonary system in the geriatric dogs.

Key words: cardiopulmonary; pulse oximeter; ECG; premicated; propofol; etomidate; diazepam; butorphanol

\footnotetext{
*Corresponding author:

Assist. Prof. Dr Shahid Hussain Dar (BVSc, AH, MVSc, PhD), Veterinary Clinical Complex, Faculty of Veterinary Sciences and Animal Husbandry, SKUAST-Kashmir, Jammu and Kashmir, 190006, India, Phone:+91 941901 7264; E-mail: shahidvsr@gmail.com
}

ISSN 0372-5480

Printed in Croatia 
S. Hussain Dar et al.: The anesthetic effect of propofol or etomidate in geriatric dogs premedicated with butorphanol and diazepam

\section{Introduction}

General anesthesia is increasingly required in canine patients. In addition to routine procedures and surgery, it also facilitates advanced diagnostic and therapeutic interventions. Despite the increasing need for general anesthesia, overall canine anesthetic mortality rates have not declined over the last two decades.

Geriatric patients are those that have completed $75 \%-80 \%$ of their expected lifespan, and now comprise a larger share of the veterinary patient population than ever before about 25\%-33\% (BAETGE and MATTHEWS, 2012). Although increased age alone does not increase a patient's anesthesia risk, concurrent health concerns are more likely in older patients. Age affects both the cardiovascular and the respiratory systems. Sedation and general anesthesia may lessen older patients' ability to compensate for cardiovascular changes. The main causes of increased anesthetic morbidity and mortality in the geriatric patient is an age-related concurrent disease. In people, this is the main cause of increased mortality, and animals are no different (MURAVCHICK, 1998). Overall, cardiac reserve is reduced and the geriatric animal is less able to compensate for adverse cardio-vascular events than younger patients (CARPENTER et al. 2005). Functional residual capacity in geriatric dogs is also reduced (PRIDE, 2005). Geriatric patients are more sensitive to anesthetic agents, thus less medication is usually required to achieve the desired clinical effect, and the drug effect is often prolonged (KANONIDOU and KARYSTIANOU, 2007).

ŞEN and KILIÇ (2018) studied induction in geriatric dogs with propofol and alphaxalone, maintained with isoflurane or sevoflurane, and found them to be safe. GUNDERSON et al. (2013) observed that the combination of midazolam-etomidate and midazolam-propofol caused minimal effects on the cardiovascular system. Etomidate caused minimal cardiovascular effects in dogs (RODRIGUEZ et al., 2012; PERK at al., 2002).

Diazepam may be combined with opioids as it lacks any analgesic effect. Hence, the amount of anesthetic drug used can be decreased, still providing excellent analgesia and producing ideal anesthesia (PSATHA et al., 2011). An ideal anesthesia should have good analgesia and excellent muscle relaxant properties.

The present study was conducted to evaluate the safety of propofol and etomidate in geriatric dogs, which were premedicated with a combination of butorphanol and diazepam.

\section{Materials and methods}

Geriatric dogs that were presented to SAC-OP-Surgery, Madras Veterinary College, Teaching Hospital, for various soft tissue surgeries were included in the study. Twelve adult dogs (males and females) were used in the study and were randomly divided into 
S. Hussain Dar et al.: The anesthetic effect of propofol or etomidate in geriatric dogs premedicated with butorphanol and diazepam

two groups viz. group P (propofol) and group E (etomidate), with six animals each. Physical examination, complete blood count determination, thorax radiography and serum biochemical analysis were performed on each dog to confirm that they were within the reference ranges prior to the surgery (ASA I-III).

The dogs were premedicated with Diazepam $0.25 \mathrm{mg} / \mathrm{kg}$ and butorphanol $0.2 \mathrm{mg} /$ $\mathrm{kg}$ fifteen minutes before anesthesia, intravenously and separately. All the dogs were preoxygenated before induction of anesthesia, using a face mask attached to a coaxial Bain breathing system. General anesthesia was induced with propofol $2 \mathrm{mg} / \mathrm{kg}$ in group P or etomidate $1 \mathrm{mg} / \mathrm{kg}$ in group $\mathrm{E}$ to effect, and the drugs were administered rapidly over a period of 45 seconds up to effect via a pre-placed IV cannula. Endotracheal intubation was attempted as soon as possible after the onset of anesthesia, which was judged using palpebral reflexes, eye position and jaw tone. If intubation was not possible, i.e. the patient attempted to withdraw its tongue or swallow, with or without vigorous coughing; more of the drug was administered - (1 mg/kg) propofol for dogs in Group P and $(0.5 \mathrm{mg} /$ $\mathrm{kg}$ ) etomidate for dogs in Group E.

Following endotracheal intubation, the endotracheal tube was attached to a co-axial semi rebreathing system delivering oxygen at a 1 liter per minute, with isoflurane added via a vaporizer set at 2 per cent.

Induction quality, recovery quality, and ataxia scores (0-3; Appendix 1) were recorded for each dog. Cardiopulmonary parameters (respiratory, pulse rates, pulse oximeter, and ECG recordings) were recorded before induction and immediately after intubation before connection to the inhalant gas machine, using a multi-parameter monitor. Blood pressure was measured by using an oscillometer.

Appendix 1. Ataxia score, induction quality score, recovery quality score

\begin{tabular}{|c|l|}
\hline Score & Characteristics \\
\hline 0 & Perfect; walking without ataxia, smooth uncomplicated induction/recovery \\
\hline 1 & Good; walking with minimal ataxia, induction/recovery uncomplicated \\
\hline 2 & OK; walking with moderate ataxia, induction/recovery difficult \\
\hline 3 & Rough; walking with significant ataxia/crawling, induction/recovery rough \\
\hline
\end{tabular}

The statistical software used in statistical analysis was SPSS 15.0 for Windows (IBM, NY, USA). Normality was tested by the Kolmogorov-Smirnov test. Body weight, induction quality, intubation quality, recovery quality was compared between the groups using a two-tailed unpaired $t$-test, and changes within the groups between pre-anesthesia and post induction was compared by a paired $t$-test. Severe adverse events (myoclonus, paddling, regurgitation, and pain on injection) were compared using the chi square test. Significance was set at $\mathrm{P}<0.05$. 
S. Hussain Dar et al.: The anesthetic effect of propofol or etomidate in geriatric dogs premedicated with butorphanol and diazepam

\section{Results}

The mean age of the six dogs in Group P was $( \pm \mathrm{SE}) 10.0( \pm 1.4)$ years, ranging from 8 to 13, and in group E 10.6 ( \pm 0.8 ) ranging from 9 to 13 years (Table 1). Mean body weight $( \pm \mathrm{SE})$ of group P was $11.68 \mathrm{~kg}( \pm 2.47)$ and in group E $12.58 \mathrm{~kg}( \pm 3.47)$. Both body weight and age differed between the groups non-significantly $(\mathrm{P}>0.5)$, and distribution of sex and breeds also differed non-significantly $(\mathrm{P}>0.5)$ between the groups.

Table 1. Age and body weight (mean $\pm \mathrm{SE}$ ) and scores (median range) for quality of induction, ease of intubation, for group $\mathrm{P}(\mathrm{n}=6)$ and group $\mathrm{E}(\mathrm{n}=6)$

\begin{tabular}{|l|c|c|}
\hline Parameters & Group P & Group E \\
\hline Body weight & $11.68 \pm 2.47(\mathrm{~kg})$ & $12.58 \pm 3.47(\mathrm{~kg})$ \\
\hline Age & $10.00 \pm 1.41($ years $)$ & $10.58 \pm 0.80$ (years) \\
\hline Induction dose & $2.20 \pm 0.17(\mathrm{mls})$ & $0.97 \pm 0.15(\mathrm{mls})$ \\
\hline Induction score & $0.33 \pm 0.21$ & $1.00 \pm 0.25$ \\
\hline Intubation score & $1.16 \pm 0.16^{*}$ & $1.83 \pm 0.16^{*}$ \\
\hline Recovery score & $1.33 \pm 0.21$ & $2.16 \pm 0.30$ \\
\hline
\end{tabular}

*Values between the groups significantly different $(\mathrm{P}<0.05)$.

Mean \pm SE induction doses (Table 1) for the propofol and etomidate groups were $2.2 \pm 0.16$ and $0.97 \pm 0.15 \mathrm{mg} / \mathrm{kg}$, respectively. The intubation score (Table 1) for group $\mathrm{P}$ was $1.16 \pm 0.16$, and for group E $1.83 \pm 0.16$, which differed significantly $(\mathrm{P}<0.05)$. Intubation was smooth in group $\mathrm{P}$, in contrast to group $\mathrm{E}$, since laryngeal reflex was intact in this group. The induction score for group $\mathrm{P}$ was $0.33 \pm 0.21$ and for group $\mathrm{E} 1.0 \pm$ 0.25 , with no significant difference $(\mathrm{P}>0.05)$, as the animals in both groups were induced without any complications.

Physiological parameters (pulse and respiratory rate; Table 2), and recordings of pulse oximeter, capillary refill time, mucous membrane color and ECG recordings did not vary significantly $(\mathrm{P}>0.05)$ between the two groups during the anesthesia

Table 2. Respiratory rate (breaths per min.) and pulse rate (per min.) for group $\mathrm{P}(\mathrm{n}=6)$ and group $\mathrm{E}(\mathrm{n}=6)($ mean $\pm \mathrm{SE})$

\begin{tabular}{|l|c|c|c|c|}
\hline \multirow{2}{*}{ Parameters } & \multicolumn{2}{|c|}{ Group P } & \multicolumn{2}{c|}{ Group E } \\
\cline { 2 - 5 } & Base line & After intubation & Base line & After intubation \\
\hline Respiratory rate & $40.00 \pm 3.23^{* a}$ & $38.28 \pm 2.24^{* a}$ & $37.71 \pm 3.86^{* a}$ & $35.71 \pm 3.06^{* a}$ \\
\hline Pulse rate & $112.67 \pm 12.18^{* a}$ & $121.17 \pm 11.99^{* a}$ & $116.67 \pm 10.64^{* a}$ & $111.33 \pm 10.21^{* a}$ \\
\hline
\end{tabular}

* Values between the groups do not differ significantly $(\mathrm{P}>0.05)$. Values within the groups with same superscript do not differ significantly $(\mathrm{P}>0.05)$ 
S. Hussain Dar et al.: The anesthetic effect of propofol or etomidate in geriatric dogs premedicated with butorphanol and diazepam

The systolic arterial pressure in the etomidate group increased after induction, but non-significantly $(\mathrm{P}>0.05)$, while it decreased non-significantly $(\mathrm{P}>0.05)$ in the propofol group, post induction. (Table 3) No significant difference was observed between the groups. Diastolic pressure also increased non-significantly $(\mathrm{P}>0.05)$ in the etomidate group, post induction.

Adverse reactions (Table 4) of the two groups differed non-significantly $(\mathrm{P}>0.05)$. Adverse reactions in the propofol group included myoclonus $(\mathrm{n}=1)$, pain on injection $(\mathrm{n}=2)$ and apnea $(\mathrm{n}=1)$, while in the etomidate group, they included regurgitation $(\mathrm{n}=$ $2)$, hypersalivation $(n=2)$ and pain on injection $(n=1)$. The recovery score differed nonsignificantly $(\mathrm{P}>0.05)$ between the two groups, while recovery in the etomidate group was slightly rougher as compared to the propofol group.

Table 3. Arterial blood pressure before and after induction with etomidate and propofol

\begin{tabular}{|l|c|c|c|}
\hline Parameter & Drugs & Baseline & After induction \\
\hline $\begin{array}{l}\text { Systolic arterial pressure } \\
(\mathrm{mm} \mathrm{Hg})\end{array}$ & Etomidate & $136.33 \pm(8.06)$ & $139.66 \pm(9.47)$ \\
\cline { 2 - 4 } & Propofol & $134.50 \pm(\mathbf{7 . 5 7})$ & $133.00 \pm(6.15)$ \\
\hline $\begin{array}{l}\text { Diastolic arterial pressure } \\
(\mathrm{mm} \mathrm{Hg})\end{array}$ & Etomidate & $100.55 \pm(\mathbf{4 . 1 8})$ & $104.22 \pm(5.25)$ \\
\cline { 2 - 4 } & Propofol & $98.16 \pm(\overline{4.37})$ & $98.88 \pm(4.96)$ \\
\hline $\begin{array}{l}\text { Mean arterial pressure } \\
(\mathrm{mm} \mathrm{Hg})\end{array}$ & Etomidate & $80.16 \pm(\overline{5.06})$ & $84.00 \pm(\overline{6.46})$ \\
\cline { 2 - 4 } & Propofol & $81.83 \pm(\underline{5.78})$ & $80.00 \pm(\underline{4.65})$ \\
\hline
\end{tabular}

Values are mean $\pm \mathrm{SE}$

Table 4. Adverse reactions in group P and Group E

\begin{tabular}{|l|c|c|}
\hline & Group P & Group E \\
\hline Myoclonus & 1 & 0 \\
\hline Paddling & 0 & 0 \\
\hline Regurgitation & 0 & 2 \\
\hline Pain on injection & 2 & 1 \\
\hline Hypersalivation & 0 & 2 \\
\hline Apnea & 1 & 0 \\
\hline
\end{tabular}

\section{Discussion}

The dosage of the two drugs, etomidate and propofol, used for induction in the present study, was lower compared to previous studies due to the fact that the use of premedication with diazepam and butorphanol produced neurolept-analgesia which created the ideal anesthetic, and therefore calmer patients for induction. Subsequently a smaller total dose for induction was required. Therefore this is beneficial in geriatric dogs as the dose of drugs should be lower as they are more sensitive compared to younger 
S. Hussain Dar et al.: The anesthetic effect of propofol or etomidate in geriatric dogs premedicated with butorphanol and diazepam

ones, so the adverse effects are reduced (KANONIDOU and KARYSTIANOU, 2007). STEGMANN and BESTER (2001) also reported that midazolam, administered at a dose of $0.2 \mathrm{mg} / \mathrm{kg}$ intravenously 2 minutes prior to propofol induction, over 60 seconds, was found to induce acute behavioral changes and decreased the dose of propofol needed. Similarly, KO et al. (2006) also reported the dose-sparing effect of benzodiazepines on the propofol induction dose. PABLO and BAILEY (1999) recommended a dose of 2 $\mathrm{mg} / \mathrm{kg}$ of etomidate following pre-medication. PASCOE et al. (1992), however, used etomidate $1 \mathrm{mg}$ per $\mathrm{kg}$ to induce anesthesia in hypotensive dogs, and anesthesia lasted for $24 \pm 4$ minutes.

The hemodynamic and cardio dynamic parameters in the present study did not change and remained with the physiological range. The current study agrees with SAMS et al. (2008) that the hemodynamic parameters did not alter following etomidate and propofol induction and remained within the physiological range. In a study comparing the hemodynamic and cardio-dynamic effects of etomidate and propofol under ketamine/ fentanyl/nitrous oxide anesthesia, it was reported that SAP and cardiac output were not changed with etomidate (BRUSSEL et al., 1989). The minimal adverse effects in the present study might be due to combining propofol or etomidate with premedicating agents which decreased the dose of both of them, and thus adverse effects were minimized (LERCHE et al. 2000). However, SAMS et al. (2008) reported that propofol caused a decrease in SAP and MAP, which was not observed with etomidate, but they used higher doses of the anesthetic drugs as compared to the present study.

In the present study more adverse effects were observed in etomidate group as compared to the propofol group. Hypersalivation and regurgitation were observed in the etomidate group in the present study. MUIR and MASON (1989) and SAMS et al. (2008) also reported that etomidate induction was associated with adverse reactions, such as myoclonic movements or vomiting, while,smooth induction was observed in propofol induction, which was also observed in the present study. However, lesser adverse effects were observed in the present study as compared to previous studies, which is probably due to the use of premedication where both an analgesic and sedative were used (MUIR and MASON, 1989).

In the present study, propofol produced fast and smooth induction, and smooth and faster recovery as compared to etomidate, and similar findings were reported by SAMS et al. (2008).

In conclusion, in a clinical setting, both propofol and etomidate, with diazepam and butorphanol as premedication, are acceptable anesthetic choices in geriatric dogs ASA $1-3$, without any major cardiopulmonary effects. Propofol is preferable than etomidate if a smooth induction and rapid recovery are desirable. 
S. Hussain Dar et al.: The anesthetic effect of propofol or etomidate in geriatric dogs premedicated with butorphanol and diazepam

\section{References}

BAETGE, C. L., N. S. MATTHEWS (2012): Anesthesia and analgesia for geriatric veterinary patients. Vet. Clin. North Am. Small Anim. Pract. 42, 643-653.

DOI: $10.1016 /$ j.cvsm.2012.05.001

BRUSSEL, T., J. L. THEISSEN, G. VIGFUSSON, P. P. LUNKENHEIMER, H. VAN AKEN, P. LAWIN (1989): Hemodynamic and cardiodynamic effects of propofol and etomidate: negative inotropic properties of propofol. Anesth. Analg. 69, 35-40.

CARPENTER, R. E., G. R. PETTIFER, W. J. TRANQUILLI (2005): Anesthesia for geriatric patients. Vet. Clin. North Am. Small Anim. Pract. 35, 571-80.

DOI: $10.1016 /$ j.cvsm.2004.12.007

GUNDERSON, E. G., V. M. LUKASIK, M. M. ASHTON, R. E. MERIDETH, R. MADSEN (2013): Effects of anesthetic induction with midazolam-propofol and midazolam-etomidate on selected ocular and cardiorespiratory variables in clinically normal dogs. Am. J. Vet. Res., $74629-635$.

DOI: 10.2460 /ajvr.74.4.629

KANONIDOU, Z., G. KARYSTIANOU (2007): Anesthesia for the elderly. Hippokratia 11, 175-177.

KO, J. C., M. E. PAYTON, A. G. WHITE, D. S. GALlOWAY, T. INOUE (2006): Effects of intravenous diazepam or microdose medetomidine on propofol-induced sedation in dogs. J. Am. Anim. Hosp. Assoc. 42, 18-27.

DOI: $10.5326 / 0420018$

LERCHE, P., A. M. NOLAN, J. REID (2000) Comparative study of propofol or propofol and ketamine for the induction of anaesthesia in dogs. Vet. Rec. 146, 571-574.

DOI: $10.1136 /$ vr. 146.20 .571

MUIR, W. W., D. E. MASON (1989): Side effects of etomidate in dogs. J. Am. Vet. Med. Assoc. 194, 1430-1434.

MURAVCHICK, S. (1998): The aging process: anesthetic implications. Acta Anaesthesiol. Belg. 49, 85-90.

PABLO, L. S., J. E. BAILEY (1999): Etomidate and telazol. Vet. Clin. North Am. Small Anim. Pract. 29, 779-792.

PASCOE, P. J., J. E. ILKIW, S. C. HASKINS, J. D. PATZ (1992): Cardiopulmonary effects of etomidate in hypovolemic dogs. Am. J. Vet. Res. 53, 2178-2182.

PERK, C., O. GUZEL, E. G. GULANBER (2002): Etomidate or Alfentanil anaesthesia in dogs and Its Effects on Pulse Oxymeter, Electrocardiography and Haematological Parameters Turk. J. Vet. Anim. Sci. 26:1021-1024.

PRIDE, N. B. (2005): Ageing and changes in lung mechanics. Eur. Respir. J. 26, 563-565.

PSATHA, E., H. I. ALIBHAI, A. JIMENEZ-LOZANO, E. ARMITAGE-CHAN, D. C. BRODBELT (2011): Clinical efficacy and cardiorespiratory effects of alfaxalone, or diazepam/ fentanyl for induction of anaesthesia in dogs that are a poor anaesthetic risk. Vet. Anaesth. Analg. 38, 24-36.

DOI: $10.1111 /$ j.1467-2995.2010.00577.x

Vet. arhiv 89 (6), 831-838, 2019 
S. Hussain Dar et al.: The anesthetic effect of propofol or etomidate in geriatric dogs premedicated with butorphanol and diazepam

RODRIGUEZ, J. M., P. M., RASCON, R. NAVARRETE-CALVO, R. J., GOMEZVILLAMANDOS, J. M. D. PEREZ, J. A. F. SARMIENTO, S. Q. CARMONA, M. M. G. MACHUCA (2012): Comparison of the cardiopulmonary parameters after induction of anaesthesia with alphaxalone or etomidate in dogs. Vet. Anesth. Analg. 39, 357-365.

DOI: 10.1111/j.1467-2995.2011.00695.x

SAMS, L., C. BRAUN, D. ALLMAN, E. HOFMEISTER (2008): A comparison of the effects of propofol and etomidate on the induction of anesthesia and on cardiopulmonary parameters in dogs. Vet. Anesth. Analg., 35:488-494.

DOI: 10.1111/j.1467-2995.2008.00417.x

SEN, Z. B., N. KILIÇ (2018): General anesthesia in geriatric dogs with Propofol-Isoflurane, Propofol-Sevoflurane, Alphaxalone-Isoflurane, Alphaxalone-Sevoflurane and their comparison of biochemical, hemodynamic and cardiopulmonary effects. Acta Sci. Vet. 46, 1519.

DOI: $10.22456 / 1679-9216.81800$

STEGMANN, G. F., L. BESTER (2001): Some clinical effects of midazolam premedication in propofol-induced and isoflurane-maintained anaesthesia in dogs during ovariohysterectomy. J. S. Afr. Vet. Assoc. 72, 214-216.

DOI: $10.4102 /$ jsava.v72i4.655

Received: 8 April 2018

Accepted: 30 April 2019

\section{HUSSAIN DAR, S., R. JAYAPRAKASH, R. SUNDAR GEORGE, S. NISSAR, M. SHAFIUZAMMA, T. ARTHANARI KANNAN: Anestetički učinak propofola ili etomidata u starijih pasa uz premedikaciju butorfanolom i diazepamom. Vet. arhiv 89, 831-838, 2019.}

\section{SAŽETAK}

Ovo je istraživanje provedeno kako bi se procijenio anestetički učinak propofola i etomidata u starijih pasa u kojih je za premedikaciju primijenjen butorfanol i diazepam. Dvanaest odraslih pasa (mužjaka i ženki) nasumično je podijeljeno u dvije skupine po šest jedinki: skupinu P (propofol) i skupinu E (etomidat). Psima je za premedikaciju apliciran diazepam u dozi od $0,25 \mathrm{mg} / \mathrm{kg}$ i butorfanol u dozi od $0,2 \mathrm{mg} / \mathrm{kg}$ intravenski i odvojeno, 15 minuta prije uvođenja u anesteziju. Opća anestezija inducirana je propofolom u dozi od $2 \mathrm{mg} / \mathrm{kg}$ u skupini P i etomidatom u dozi od $1 \mathrm{mg} / \mathrm{kg}$ u skupini E do učinka, a pripravci su primijenjeni brzo tijekom 45 sekundi do učinka. Za svakog su psa zabilježeni kvaliteta uvođenja u anesteziju, oporavka i intenzitet ataksije. Srčano-plućni pokazatelji (disanje, srčani puls, pulsna oksimetrija i EKG) zabilježeni su prije uvođenja u anesteziju i odmah nakon intubacije te prije spajanja na respirator koristeći se multiparametrijskim monitorom. Prosječne \pm SE doze za uvođenje u anesteziju bile su $2,2 \pm 0,16$ za propofol i $0,97 \pm 0,15 \mathrm{mg} / \mathrm{kg}$ za etomidat. U skupini u kojoj je dan propofol primijećena je neometana intubacija u usporedbi sa skupinom u kojoj je dan etomidat, zbog izostanka laringealnog refleksa. Fiziološki pokazatelji (disanje, srčani puls, pulsna oksimetrija, vrijeme punjenja kapilara, boja sluznica, EKG i krvni tlak) nisu znakovito varirali u skupinama za vrijeme anestezije. Više je neželjenih reakcija bilo u skupini kojoj je dan etomidat, ali razlike nisu bile znakovite. Zaključujemo da ni propofol ni etomidat nemaju znatnijih negativnih učinaka na srčano-plućni sustav starijih pasa kojima je za premedikaciju apliciran butorfanol i diazepam.

Ključne riječi: srčano-plućni sustav; pulsna oksimetrija; EKG; premedikacija; propofol; etomidat; diazepam; butorfanol 